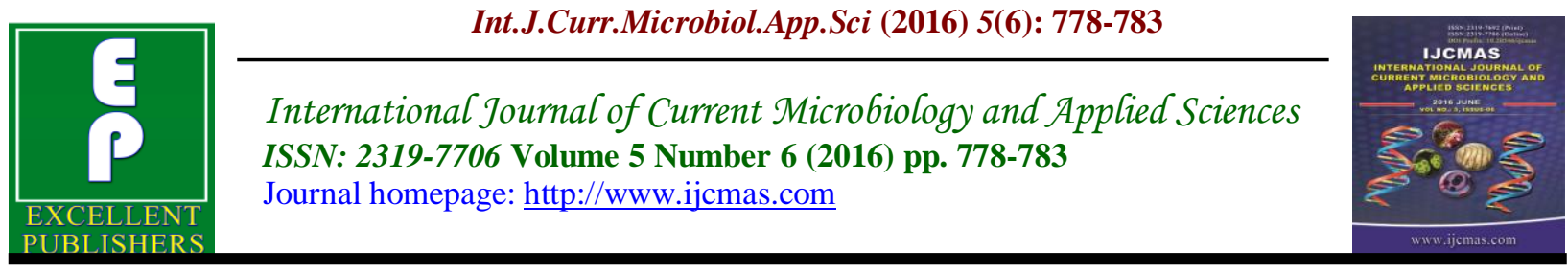

Original Research Article

http://dx.doi.org/10.20546/ijcmas.2016.506.086

\title{
Bacteriological Study of Diarrheas in Children
}

\author{
J. Srinivasarao, Chinnoutpalli, D. Varalakshmi and D. Sarada* \\ Department of Microbiology, Siddhartha Medical College, Vijayawada, Andhra Pradesh, India \\ *Corresponding author
}

\begin{tabular}{|c|c|}
\hline & \multirow{5}{*}{$\begin{array}{l}\text { A B S T R A C T } \\
\text { Diarrheas are one among the commonest causes of morbidity and mortality in } \\
\text { children in developing countries like India. Children below the age group of } 5 \text { years } \\
\text { in rural areas and of low socio-economic status are most commonly affected due to } \\
\text { various reasons like unprotected water supply, poor personal hygiene, illiteracy and } \\
\text { malnutrition. The Study was conducted on } 100 \text { children below the age group of } 12 \\
\text { years to identify the prevalent organism causing diarrhea in Guntur. Stool samples } \\
\text { were processed and the causative agent was identified using standard } \\
\text { microbiological techniques. Male children were affected more than female children } \\
\text { and the commonest age group involved was } 0-5 \text { years. Incidence was common in } \\
\text { rural population and in low-socioeconomic group. Escherichia coli was the } \\
\text { commonest isolate with an incidence rate of } 54 \% \text { followed by Klebsiella (17\%), } \\
\text { Pseudomonas, Salmonella(1\% each) and mixed infection with Escherichia coli and } \\
\text { Klebsiella( } 6 \%) \text {. Most of the isolates were sensitive to Ciprofloxacin, Norfloxacin } \\
\text { and Gentamycin. On follow-up, recovery rate was } 95 \% \text { and mortality rate was } \\
\text { observed to be } 5 \% \text {. The isolate and the antibiotic sensitivity pattern helps the } \\
\text { paediatrician in treating children with complaints of diarrhea. }\end{array}$} \\
\hline Keywords & \\
\hline & \\
\hline & \\
\hline & \\
\hline
\end{tabular}

\section{Introduction}

In developing countries like India, diarrheas are one of the commonest causes of morbidity and mortality among children. The incidence and mortality is high in Rural areas and unhealthy localities of Urban areas mainly due to poverty, illiteracy, bad personal hygiene, lack of health education and other factors. About 1.5 million children under the age group of five years die every year owing to acute diarrhea. Diarrheal diseases cause a heavy economic burden on health resources, as children with such diseases occupy about $15 \%$ of Paediatric beds in some developing countries.
An individual below 12 yrs of age was considered as a child for the study. A child suffers on an average 10 to 15 episodes of diarrhea and of these, three to five occur in the first five years of life. A child with multiple episodes of diarrhea suffers from most severe form of protein energy malnutrition.

About $5 \%$ of diarrhea cases in the community become chronic and last more than 2 weeks. Persistent colonization of upper small intestines by microbes, Dietary allergies, Carbohydrate intolerance caused 
by damage to the brush borders of intestinal mucosa resulting in low levels of disaccharidases, Infant and children with decreased host immunity, delayed repair of intestinal damage because of associated protein energy malnutrition are more prone to suffer protracted diarrhea.

Etiological agents responsible for infective diarrheas include microorganisms like Bacteria, Viruses, Fungi and Parasites. Our study was aimed at isolating and identifying the Bacterial agents involved in causing acute and chronic diarrheas in children attending Department of Paediatrics, Government General Hospital, Guntur, Andhra Pradesh.

\section{Materials and Methods}

One hundred stool samples were collected from children below 12 years suffering with Acute and Chronic Diarrhea and Gastroenteritis from both out-patients and In-patients of Paediatric Unit, Government General Hospital, Guntur for the study.

Samples Collected from patients were processed in the Department of Microbiology for the isolation and identification of causative organisms. Fifty stool samples were collected from healthy children attending Government General Hospital for complaints other than diarrhea and Gastro enteritis as control group.

\section{Collection of Specimens}

The specimen was collected prior to the administration of antibiotics in a sterile container used in stool collection with a small plastic spoon attached to the inside of screw cap. The screw cap is removed and a single spoonful i.e., $5 \mathrm{ml}$ of stool collected directly into the container and the cap is replaced tightly. The stool sample is collected in sterile condition without contamination with patient's urine. All the collected samples were processed in the Department of Microbiology, Guntur Medical College, Guntur within one hour of collection. A loopful of collected stool sample is inoculated on Basal and Selective media and processed by Standard Microbiological Techniques and tested for Antibiotic Sensitivity for the isolate.

\section{Results and Discussion}

A total of one hundred stool samples were collected from children below 12 years suffering with diarrhea and gastroenteritis in clinical wards of Pediatrics, Government General Hospital, Guntur. A total of 50 stool samples were collected from the same age group of healthy children as control.

There were 64 male and 36 female children in the study group of 100 . Of these, 91 were in 0-5 years age group, among which 60 were male and 31 female children and four male and 5 female children in 5-12 years (Table:I). In the present study, male children $(64 \%)$ were most affected than female (36\%) and studies by various authors, Surya kanta samal et al., 2008, Vyas kumar Rathaur et al., 2014(54.6\% male, $45.4 \%$ female) and Sunil Kumar et al., 2015 (59\% male and $41 \%$ female) reported male preponderance.

Cases from Rural area were 64 and Urban were 36(Table II) in the study group which is in accordance with studies by Vyas Kumar Rathaur et al. (2015) reporting an incidence of $57.5 \%$ in rural children and $42.5 \%$ in children living in urban set-up.

Among 100 cases, 88 belong to Low Socioeconomic status and 12 to middle Socioeconomic group and this correlates with studies by Seema Kumara et al. (2013) 
reporting an incidence of $66.6 \%$ in Lower income group and $33.3 \%$ in middle income group and Manoj Kumar et al. observed the incidence to be $74.5 \%$ in Low income group followed by Middle income $21.5 \%$ and least in High income group $4 \%$.

Among the 100 samples, Escherichia coli was isolated in 54(54\%), Klebsiella species 17(17\%), Salmonella species 1(1\%) and Pseudomonas aeruginosa 1(1\%). Incidence of mixed infection with Escherichia coli and Klebsiella was (6\%), 12 (12\%) were culture negative and in nine samples nonpathogenic organisms (9\%) were isolated. Among the total of 54 Escherichia coli isolated, 48 were in the age group between
$0-5$ years $(88.8 \%)$ and $6(11.1 \%)$ in 512 years. In this study, the Predominant organism isolated in diarrheal cases $(46 \%)$ and acute gastro enteritis (8\%) were Escherichia coli (Table III \& IV).

Escherichia coli was the predominant organism isolated in our study and this correlates with studies by various authors from different areas reporting that the frequently isolated organism is Escherichia coli. Surya Kanta Samal, et al. (2008) reported an isolation of $75.5 \%$ Escherichia coli, Haricharan K.R. et al. (2013) as $42.66 \%$ and Vyas Kumar, et al. (2014) as $44.2 \%$. Other bacterial isolates were similarly reported by these authors.

Table.1 Age Wise and Sex Wise Incidence

\begin{tabular}{|l|c|c|c|}
\hline \multirow{2}{*}{ Age } & \multicolumn{2}{|c|}{ Sex } & \multirow{2}{*}{ Total } \\
\cline { 2 - 3 } & Male children & Female children & \\
\hline $0-5$ & 60 & 31 & 91 \\
\hline $5-12$ & 4 & 5 & 9 \\
\hline & 64 & 36 & 100 \\
\hline
\end{tabular}

Table.2 Socio-Economic Status

\begin{tabular}{|l|c|}
\hline Urban & 36 \\
\hline Rural & 64 \\
\hline Total & 100 \\
\hline
\end{tabular}

Table.3 Clinical Incidence Of Organisms Isolated

\begin{tabular}{|l|c|c|c|}
\hline $\begin{array}{l}\text { Names of Pathogenic } \\
\text { organisms isolated }\end{array}$ & Diarrhea & Gastroenteritis & Total \\
\hline Escherichiac coli & 46 & 8 & 54 \\
\hline Klebsiella species & 5 & 2 & 17 \\
\hline Esch.coli and Klebsiella & 3 & 3 & 6 \\
\hline Pseudomonas aeruginosa & - & 1 & 1 \\
\hline Salmonella species & 1 & - & 1 \\
\hline Non Pathogenic organism & 6 & 3 & 9 \\
\hline Culture negative & 7 & 5 & 12 \\
\hline Total & 68 & 32 & 100 \\
\hline
\end{tabular}


Table.4 Age Wise and Sex Wise Incidence

\begin{tabular}{|l|c|c|c|}
\hline $\begin{array}{l}\text { Names of pathogenic } \\
\text { organisms isolated }\end{array}$ & $\begin{array}{c}\text { Male } \\
\text { children }\end{array}$ & $\begin{array}{c}\text { Female } \\
\text { children }\end{array}$ & Total \\
\hline Escherichia coli & 30 & 24 & 54 \\
\hline Klebsiella species & 10 & 7 & 17 \\
\hline Esch.coli and Klebsiella & 4 & 2 & 6 \\
\hline Salmonella species & - & 1 & 1 \\
\hline Pseudomonas aeruginosa & 1 & - & 1 \\
\hline Non Pathogenic organism & 4 & 5 & 9 \\
\hline Culture negative & 8 & 4 & 12 \\
\hline Total & 57 & 43 & 100 \\
\hline
\end{tabular}

Table.5 Table Showing Sensitivity Pattern of the Isolated organisms

\begin{tabular}{|l|c|c|c|c|c|}
\hline \multirow{2}{*}{$\begin{array}{l}\text { Names of the pathogenic } \\
\text { organisms isolated }\end{array}$} & \multicolumn{5}{|c|}{ Names of the antibiotics } \\
\cline { 2 - 6 } & Furazolidine & Cotrimoxozole & Ciprofloxacin & Norfloxacin & Gentamicin \\
\hline Esch. coli & Nil & Nil & 54 & 54 & 54 \\
\hline Klebsiella species & Nil & Nil & 17 & 17 & 17 \\
\hline $\begin{array}{l}\text { Esch.coli and Klebsiella } \\
\text { sp }\end{array}$ & Nil & Nil & 6 & 6 & 6 \\
\hline Salmonella species & Nil & Nil & 1 & 1 & Nil \\
\hline Pseudomonas aeruginosa & Nil & Nil & 1 & Nil & Nil \\
\hline
\end{tabular}

Table.6 Case Follow Up

\begin{tabular}{|l|c|c|c|}
\hline & Diarrhoea & Gasteroenteritis & Total \\
\hline Recovery & 69 & 26 & 95 \\
\hline Mortality & 4 & 1 & 5 \\
\hline Total & 73 & 27 & 100 \\
\hline
\end{tabular}

Antibiotic sensitivity pattern in the study reveals that Escherichia coli responded predominantly to Ciprofloxacin, Norfloxacin and Gentamicin, Klebsiella to Ciprofloxacin, Norfloxacin and Gentamicin, Salmonella to Ciprofloxacin, Norfloxacin and Pseudomonas aeruginosa to Ciprofloxacin. All isolates of Escherichia coli are resistant to Furazolidine and Co -trimoxazole, salmonella to Furazolidine and $\mathrm{Co}$ trimoxazole and Pseudomonas to Furozolidine and Co-trimoxazole(Table V).

Studies reported by Mamatha Ballal et al. in India have shown a similar pattern of antibiotic sensitivity of Escherichia coli to Ciprofloxacin, Gentamicin and Norfloxacin.

Follow-up study of the cases revealed that the total deaths were 5\%, among which $4 \%$ were due to diarrhea and $1 \%$ due to acute gastro-enteritis (Table VI). Analysis of Diarrheal deaths by Dutta et al. reported an incidence of $17.1 \%$ and our study has a lower rate.

Among fifty control group Escherichia coli was isolated in 24 cases, Klebsiella in 6 cases in the age group of 5-12years and no bacterial isolates among $0-5$ age group. The 
normal colon strains belong to the early ' 0 ' groups 1, 2, 3, 4 etc. while the Enteropathogenic stains belong to the late ' 0 ' groups 26, 55, 86, 111 etc., and this may account for Escherichia coli isolated in 24 cases of diarrhoea in 5-12years. Klebsiella species may occur as commensal in the intestine and may turn pathogenic in 05 years age group by colonization.

In conclusion, from this study it can be concluded that the predominant isolate in pediatric diarrheas is Escherichia coli and its sensitivity pattern revealed that it is susceptible to Cliprofloxacin, Norfloxacin and Gentamycin. In view of this observation in this study the pediatricians can take the advantage to start the treatment with one of the above antibiotics at the earliest for the treatment of cases with diarrheas and acute gastro-enteritis.

\section{References}

Beena Uppal, Naz Parween, Prabhav Aggarwal, Shyam Kishore Kumar. 2015. A Comparative Study of Bacterial and Parasitic Intestinal Infections in India. J. Clin. Diagn. Res., 9(3): DC01-DC04.

Daniel, R., Diniz-Santos, Jose, S., Snatana, Junaura, R., Barretto, Maria Goreth. 2005. M. Andrada; Luciana R. Silva. Epidemiological and microbiological aspects of acute Bacterial Diarrhea in children from Salvador, Bahia, Brazil. Brazilian J. Infect. Dis., Vol. 9, No. 1, Salvador, Feb. 2005.

Dutta, et al. 1995. Analysis of Diarrheal Deaths, Indian Paediatrics, Volume. 32.

Duru, E.E., O.E. Agbagwa, F.E. Umoren. Bacterial Agents associated with Infantile Diarrhea and Their Antibiotics Susceptibility Pattern in Port Harcourt, South- South, Nigeria.
J. Public sci. Public Health, Vol. 3, No. 1, 01-12.

Haricharan, K.R., Shrinivasa, B.M., Vatsala Kumari. 2013. Clinical and Bacteriological Study of Acute Diarrhea in Children. J. Evol. Med. Dent. Sci., June 2013, http://www.jemds.com/latestarticles.php?at_id=1346.

Hossain, Md. Asif, Kohinoor Akter Raton and Rashed Noor. 2013. Bacteriological study of Stool samples collected from children suffering from Diarrhea. J. Global Biosci., Vol. 2(5), pp. 160-165.

Mamatha Ballal, Suganthi, M., Devadas, Rituparna Chakraborthy, Vignesh Shetty. 2014. Emerging trends in Etioloogy and Antimicrobial Susceptibility Pattern of Enteric Pathogens in Rural Coastal India. Int. J. Clin. Med., Vol. 5, No. 7 (2014), Article ID: 44744, 8 pages.

Manoj Kumar, Manisha Ramakrishana, Koram, Lalith Kumar. 2014. Study of Various Causative Factors of Diarrheal Diseases with Special Reference to Bacteriological Profile among 0 to 5 Years Age Group. Int. J. Scientific Study, Vol. 2, Issue 3, pp 47-52.

Mohammed Reza Ismaeili Dooki, Ramazan Rajabnia, Rahim Barari Sawadkohi. et al. 2014. Bacterial enteropathogens and antimicrobial susceptibility in children with acute diarrhea in Babol, Iran. Caspian J. Intern. Med., 1(5): 30-34.

Das, S., R. Saha, S. Singhal. 2007. Enteric Pathogens in North Indian Patients with Diarrhea. Indian J. Community Med., Vol. 32, Issue 1 page 27-31.

Seema Kumari, Sanjeev Kumar Ambasta. Isolation of Microorganisms from Stool Sample of Diarrhea patient and effect of antibiotics and Herbal 
extract. CIBTech J. Microbiol., Vol. 2(2) pp. 24-32.

Subitha Lakshminarayanan, Ramakrishnan Jayalakshmy. 2015. Diarrheal Diseases among Children in India: Current Scenerio and future perspectives. J. Nat. Sci. Biol. Med., 6(1)24-28.

Sunil Kumar, D., Chavan, K.H. Harshan. 2015. Aerobic Bacteriological Study with their Antibiogram in Children Acute Diarrhea in North East Karnataka, India. Int .J. Curr. Microbiol. App.Sci., 4(11): 700-706.
Surya Kanta Samal, Hemant Kumar Khuntia, Prafulla Kumar Nanda, et al. 2008. Incidence of Enteropathogens among Hospitalized Diarrhea patients from Orissa, India. Jpn. J. Infect. Dis., 61: 350-355, 2008.

Vyas Kumar Rathaur, Monika Pathania, Apama Jayara, Neeraj Yadav. 2014. Clinical Study of Acute Childhood Diarrhea Caused by Bacterial Enteropathogens. J. Clin. Diagn. Res., 8(5): PC01-PC05.

\section{How to cite this article:}

Srinivasarao, J., Chinnoutpalli, D. Varalakshmi and Sarada, D. 2016. Bacteriological Study of Diarrheas in Children. Int.J.Curr.Microbiol.App.Sci. 5(6): 778-783. doi: http://dx.doi.org/10.20546/ijcmas.2016.506.086 